\title{
Analisis Biaya Hidup Aset pada Infrastruktur Pengangkatan Air Baku di Daerah Karst
}

\section{MUHAMMAD LUQMAN NUR ROUF ARIFIN ${ }^{1}$, TEUKU FAISAL FATHANI ${ }^{2}$, HENRICUS PRIYOSULISTYO ${ }^{3}$}

1. Departemen Teknik Sipil dan Lingkungan, Fakultas Teknik, Universitas Gadjah Mada, Yogyakarta, INDONESIA

2. Departemen Teknik Sipil dan Lingkungan, Fakultas Teknik, Universitas Gadjah Mada, Yogyakarta, INDONESIA. Pusat Unggulan dan Inovasi Teknologi Mitigasi

Kebencanaan UGM (GAMA-InaTEK)

3. Departemen Teknik Sipil dan Lingkungan, Fakultas Teknik, Universitas Gadjah Mada, Yogyakarta, INDONESIA

Email: muhammad.luqman.nur.rouf.arifin@mail.ugm.ac.id tfathani@ugm.ac.id priyo_ugm@ugm.ac.id

\begin{abstract}
ABSTRAK
Kawasan karst Gunungsewu yang terbentang dari Kabupaten Gunung Kidul, Wonogiri hingga Pacitan memiliki banyak lembah kering dan mengalami kelangkaan air permukaan. Kekeringan melanda saat musim kemarau datang, sedangkan pada saat musim penghujan, umumnya air ditampung di penampungan air hujan (PAH) sederhana. Adanya program Pengangkatan Air Tenaga Surya (PATS) di beberapa lokasi di Kawasan karst Gunungsewu telah berhasil membantu warga dalam mengurangi masalah kekeringan. Penelitian ini menganalisis biaya hidup aset infrastruktur pengangkatan air baku menggunakan energi terbarukan (PATS) dan Pengangkatan Air Tenaga Diesel (PATD) di daerah karst. Lokasi yang dipilih adalah di Dusun Banyumeneng, Kabupaten Gunung Kidul yang mulai beroperasi tahun 2016. Analisis biaya hidup aset meliputi biaya awal, biaya perawatan dan perbaikan, biaya penggantian komponen dan biaya penghapusan. Hasil analisis nilai kini aset menunjukkan bahwa nilai pada akhir umur layan PATS Banyumeneng sebesar (+)Rp66.240.298,00 untuk penggunaan energi surya, dan (-)Rp30.997.539,00 untuk penggunaan energi diesel. Nilai positif pada hasil analisis biaya hidup aset PATS menunjukkan bahwa infrastruktur PATS Banyumeneng menguntungkan secara ekonomi untuk dibangun dan beroperasi menggunakan tenaga surya.
\end{abstract}

Kata kunci: biaya hidup aset, pengangkatan air tenaga surya, pengangkatan air tenaga diesel, nilai kini asset, karst Gunungsewu

\section{ABSTRACT}

The Gunungsewu karst area which stretches from Gunung Kidul Regency, Wonogiri to Pacitan has many dry valleys and experiences a scarcity of surface water. Drought occurs when the dry season comes, while during the rainy season, water is generally stored in simple rainwater storage (PAH). The existence of a Solar Water Pumping System (PATS) in several locations in the 
Gunungsewu karst area has succeeded in helping residents in reducing drought problems. This study analyzes the life cycle cost of water supply infrastructure using renewable energy technology (PATS) and diesel technology (PATD) in the karst area. The chosen location was in Banyumeneng Hamlet, Gunung Kidul Regency which began operations in 2016. Analysis of life cycle cost includes initial costs, maintenance and repair costs, replacement costs and salvage value. Present value of assets show that the value at the end of the service life of PATS Banyumeneng is (+)Rp66,240,298.00 for the use of solar energy, and (-)Rp 30,997,539.00 for the use of diesel energy. The positive value on the results of the PATS life cycle cost analysis shows that the PATS Banyumeneng infrastructure is economically profitable to build and operate.

Keywords: life cycle cost, solar water pumping system, diesel powered water pumping system, present value of asset, Gunungsewu karst area 


\section{PENDAHULUAN}

Indonesia memiliki kawasan karst dengan luas hingga lebih dari 15,4 juta hektar yang tersebar di beberapa wilayah di Pulau Jawa, Sumatera, Sulawesi dan pulau-pulau lainnya (Widiyanti dan Dittman, 2014). Diantara kawasan karst tersebut, daerah karst Gunungsewu dianggap sebagai percontohan dari karst daerah tropis dengan luas mencapai $3.300 \mathrm{~km}^{2}$ yang terbentang dari Daerah Istimewa Yogyakarta, Provinsi Jawa Tengah, dan Provinsi Jawa Timur (Adji dkk., 1999). Kawasan karst dicirikan dengan banyaknya lembah kering dan langkanya sungai permukaan. Hal ini disebabkan kondisi hidrologi kawasan karst yang memiliki jenis batuan yang mudah larut dan berkembang baiknya porosifitas sekunder pada batuan karst. Karakterisitik tersebut membuat kawasan karst memiliki permasalahan berupa kelangkaan air bersih (Ford dan Williams, 2007). Pada daerah karst Gunungsewu, air permukaan masih dapat ditemukan di beberapa tempat namun kebanyakan berada jauh dari pemukiman. Kondisi tanah bebatuan dan morfologi berbukit, serta minimnya akses listrik menyebabkan sumber air permukaan tersebut sulit untuk dieksplorasi (Setiawan dkk., 2014a).

Kabupaten Gunungkidul merupakan salah satu daerah di kawasan karst Gunungsewu yang mengalami kelangkaan pasokan air bersih. Laporan Kinerja Perusahaan Daerah Air Minum (PDAM) tahun 2015 menyebutkan bahwa hanya sekitar 58,3\% masyarakat yang mendapatkan akses air bersih melalui pelayanan PDAM, 41,7\% sisanya mengandalkan pengelolaan air mandiri ataupun menggunakan bak Penampung Air Hujan (PAH). Masyarakat di Gunungkidul menghadapi masalah yang lebih rumit pada musim kemarau. Masyarakat dengan pendapatan rata-rata Rp400.000,00 harus membeli air bersih dari penyedia air dengan harga Rp100.000,00 sampai Rp150.000,00 per tangki 5.000 liter (Wahyuni dkk., 2015).

Pemerintah daerah setempat telah melakukan berbagai upaya untuk mengatasi permasalahan kelangkaan pasokan air bersih di kabupaten tersebut, salah satu solusi yang diterapkan adalah Pengangkatan Air Tenaga Surya (PATS). Pengangkatan air tenaga surya menggunakan teknologi panel surya yang berfungsi menuai energi dari matahari. Energi matahari tersebut selanjutnya digunakan untuk menggerakkan pompa. Teknologi ini sesuai untuk diterapkan di daerah pelosok yang memiliki sumber mata air namun tidak memiliki akses terhadap listrik (Setiawan, 2014).

Dalam penelitian ini, dilakukan analisis biaya hidup aset infrastruktur pengangkatan air baku di Dusun Banyumeneng Kabupaten Gunungkidul. Pengangkatan Air Tenaga Diesel (PATD) di daerah ini dibangun tahun 2000, sedangkan Pengangkatan Air Tenaga Surya (PATS) dibangun 2016 yang diharapkan dapat beroperasi selama 20 tahun. Analisis biaya hidup aset pada infrastruktur PATS dan PATD ini diharapkan dapat menjadi salah satu referensi analisis ekonomi teknik untuk infrastruktur pengangkatan air baku yang selanjutnya dapat berkonstribusi dalam pengentasan masalah pemenuhan kebutuhan air baku bagi masyarakat yang tinggal di kawasan karst.

\section{PERHITUNGAN BIAYA HIDUP ASET}

Biaya hidup aset adalah keseluruhan biaya saat ini maupun masa mendatang yang berhubungan dengan sistem, yang disajikan dalam total biaya saat ini (present value) selama periode tertentu. Tujuan dari analisis biaya hidup aset adalah untuk memperkirakan biaya keseluruhan dari proyek dan memilih desain yang tepat untuk memastikan suatu infrastruktur dapat memberikan biaya paling rendah dalam kepemilikan dan sebanding dengan fungsi dan kualitasnya (Agrawal dan Tiwari, 2010). Komponen dari biaya hidup aset 
yang diperhitungkan yaitu: biaya awal, biaya perawatan dan perbaikan, biaya penggantian dan biaya penghapusan, dengan asumsi suku bunga tahunan sebesar $7,99 \%$ per tahun (Bank Indonesia, 2018).

\subsection{Biaya Awal}

Biaya awal merupakan biaya yang mencakup penggunaan suatu sistem teknologi (panel surya, generator diesel, pompa dan sistem distribusi) dan biaya lain yang dibutuhkan untuk pembangunan sistem. Pada penelitian ini, biaya awal bersumber dari rencana anggaran biaya (RAB) yang dimiliki oleh pelaksana kegiatan PATS dan PATD.

\subsection{Biaya Perawatan dan Perbaikan}

Biaya perwatan dan perbaikan merupakan biaya yang diterima dan dikeluarkan selama fase operasional. Biaya pemasukan PATS dan PATD berasal dari pembayaran oleh konsumen sebesar Rp8.000,00/m³. Selain itu, biaya pengeluaran PATS dan PATD digunakan untuk honor operator sebesar $45 \%$ dari pendapatan, sedangkan biaya rutin perawatan PATS sebesar $5 \%$ dari pendapatan dan biaya rutin perawatan PATD adalah nilai real. Adapun biaya perawatan dan perbaikan tahunan dari PATS dan PATD menggunakan Persamaan 1.

$$
P_{M R}=M_{n} *\left[\frac{1}{i(i+1)^{n}}\right]
$$

dimana $P_{M R}$ adalah nilai kini untuk biaya perawatan dan perbaikan sistem, $M$ adalah biaya perawatan dan perbaikan sistem rata-rata, $i$ adalah suku bunga tahunan, dan $n$ adalah umur layan

\subsection{BiayaPenggantian}

Jumlah dan waktu penggantian dari komponen PATS dan PATD tergantung dari umur layan komponen tersebut. Pada penelitian ini diasumsikan bahwa umur layan untuk komponen pompa terendam (submersible) dan sistem pengontrol (controller) adalah selama 5 tahun (GIZ, 2006). Jika $R_{n}$ adalah biaya penggantian komponen PATS dan PATD setiap lima tahun, maka nilai kini untuk biaya total penggantian diuraikan dalam Persamaan 2.

$$
P_{R}=R_{n} *\left[\frac{1}{i(i+1)^{n}}\right]
$$

dimana $P_{R}$ adalah nilai kini untuk biaya penggantian komponen sistem, dan $R_{n}$ adalah biaya penggantian komponen tahunan.

\subsection{BiayaPenghapusan}

Biaya penghapusan didefinisikan sebagai biaya yang dikeluarkan dalam pembongkaran (demolition) dan pembuangan (disposal) dari sistem. Pada penelitian ini, diasumsikan bahwa komponen yang bisa digunakan kembali setelah umur layan adalah panel surya, pipa Highdensity polyethylene (HDPE), tandon utama dan tandon distribusi. Jika $S$ merupakan biaya penghapusan pada akhir dari umur layan sistem, maka perhitungan nilai kini untuk biaya menggunakan Persamaan 3.

$$
P_{S}=S *\left[\frac{1}{i(i+1)^{n}}\right]
$$


dimana $P_{S}$ adalah nilai kini untuk biaya penghapusan sistem, dan $S$ adalah biaya penghapusan.

\subsection{Total Net Present Value}

Setelah mengetahui masing-masing biaya dari biaya awal, biaya perawatan dan perbaikan, biaya penggantian dan biaya penghapusan, maka total dari biaya tersebut diakumulasi dengan metode Net Present Value (NPV). Hasil akhir NPV bernilai positif menunjukkan bahwa pembangunan infrastruktur tersebut menguntungkan secara ekonomi untuk dilaksanakan. Sebaliknya, hasil akhir NPV bernilai negatif menunjukkan bahwa pembangunan infrastruktur tersebut tidak menguntungkan secara aspek ekonomi. Persamaan 4 menunjukkan formula untuk menentukan $N P V$.

$$
N P V=P_{i}+P_{M R}+P_{R}+P_{S}
$$

\section{HASIL DAN PEMBAHASAN}

Biaya awal dari pembangunan infrastruktur PATS Banyumeneng merupakan jumlah harga dari 3 komponen PATS, yaitu: komponen pembangkitan daya, komponen pengangkatan air dan komponen distribusi air. Pada biaya awal PATS meskipun metode pelaksanaan pada pembangunan PATS adalah gotong royong oleh masyarakat penerima manfaat namun pada penelitian ini komponen biaya tenaga atau jasa diasumsikan sebesar $20 \%$. Total biaya awal pembangunan PATS sebesar Rp337.413.472,00, sedangkan biaya awal untuk pembangunan PATD Rp294.512.220,00.

Persamaan 1 digunakan untuk menghitung nilai kini dari biaya perawatan dan perbaikan sistem selama 20 tahun umur layan, dengan asumsi bahwa harga pembelian air per $\mathrm{m}^{3}$ naik sebesar $15 \%$ per tahun. Gambar 1 menunjukkan kenaikan pendapatan PATS selama 20 umur layan. Dari analisis biaya perawatan dan perbaikan diketahui bahwa pada komponen biaya PATS dan PATD selalu menghasilkan nilai positif. Hal ini dikarenakan ketentuan awal bahwa honor operator adalah $45 \%$ dari pendapatan bulanan.

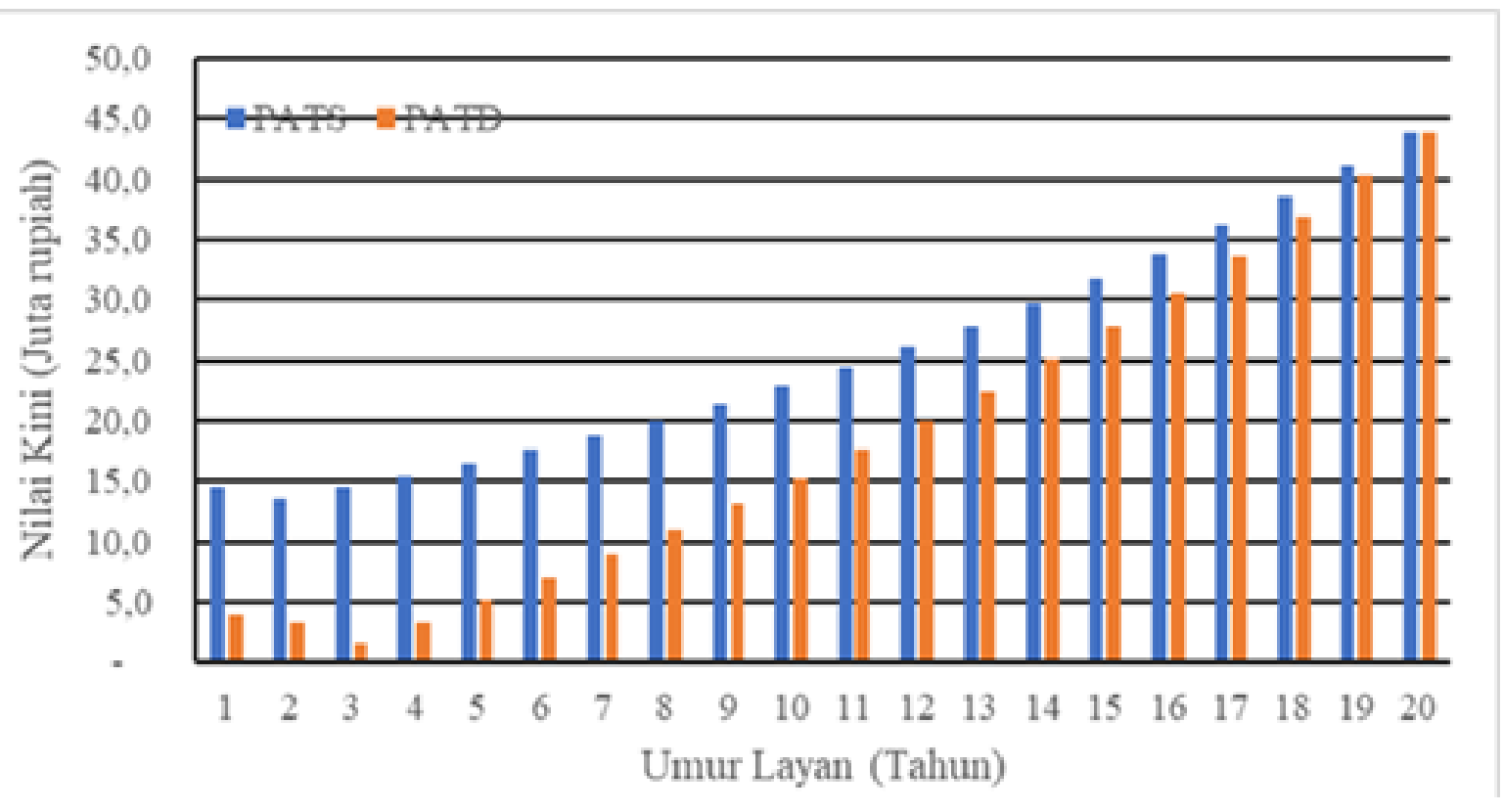

Gambar 1. Hasil perhitungan biaya perawatan dan perbaikan 
Biaya penggantian memperhitungkan penggantian komponen penting yaitu pompa, generator diesel dan sistem pengontrol. Biaya yang diperlukan untuk komponen utama sistem PATS Banyumeneng adalah Rp41.700.000,00 untuk penggantian pompa dan Rp16.158.750,00 untuk penggantian sistem pengontrol. Biaya penggantian pada PATD ditambah dengan unit generator diesel sebesar Rp58.920.000,00. Persamaan 2 digunakan untuk menghitung biaya penggantian komponen PATS dan PATD selama 20 tahun umur layan. Jumlah biaya yang dikeluarkan pada tiap 5 tahun penggantian sistem ditunjukkan pada Gambar 2. Dari Gambar 2 tersebut diketahui total nilai kini untuk biaya penggantian komponen PATS adalah sebesar Rp86.290.071,00, yang jauh lebih rendah dibanding biaya penggantian komponen PATD sebesar Rp114.273.192,00. Perbedaan yang cukup besar pada biaya penggantian tersebut dikarenakan perbedaan teknologi yang digunakan dalam komponen pembangkitan daya PATS dan PATD. Teknologi panel surya pada komponen pembangkitan daya PATS diharapkan memiliki umur layan selama 25 tahun, dimana umur layan panel surya tersebut lebih panjang dari 20 tahun umur layan PATS. Sebaliknya, umur layan generator diesel pada komponen pembangkitan daya PATD adalah 10 tahun, sehingga memerlukan sekali penggantian generator diesel selama 20 tahun umur layan PATD. Biaya penghapusan dihitung berdasarkan estimasi komponen yang masih dapat digunakan kembali (reuse) untuk kegiatan lain. Estimasi penurunan nilai sisa atau penyusutan dari komponen panel surya sekitar $50 \%$, sedangkan penurunan nilai sisa komponen pipa HDPE dan tandon distribusi adalah $25 \%$. Hal ini dikarenakan kedua komponen tersebut berada di tempat terlindung dan mengalami kontak lingkungan minimal sehingga lebih awet. Nilai kini dari komponen tersebut kemudian dihitung menggunakan Persamaan 3. Hasil analisis menunjukkan total nilai kini untuk biaya penghapusan PATS adalah sebesar Rp16.817.372,00; yang hampir dua kali lebih besar dari biaya penghapusan PATD sebesar Rp9.373.812,00. Tingginya nilai kini pada biaya penghapusan PATS disebabkan komponen panel surya masih dapat digunakan pada akhir umur layan. Komponen panel surya PATS diprediksi masih memiliki daya keluaran $\pm 70 \%$ dari kondisi awal. Sehingga dengan perencanaan dan pelaksanaan yang baik, komponen panel surya masih dapat digunakan untuk infrastruktur penerangan jalan umum, sumber listrik sekunder rumah dan kebutuhan lainnya.

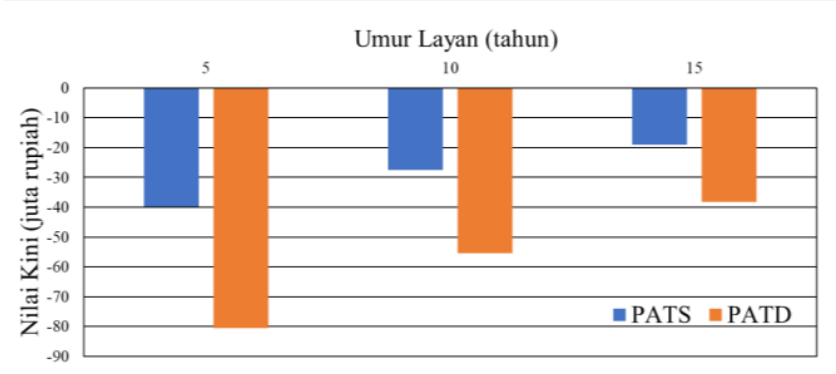

\section{Gambar 2. Biaya penggantian komponen PATS dan PATD}

Dari hasil analisis biaya awal, biaya perawatan dan perbaikan, biaya penggantian dan biaya penghapusan, selanjutnya Persamaan 4 digunakan untuk menghitung Net Present Value (NPV). Hasil perhitungan menunjukkan bahwa NPV untuk infrastruktur PATS adalah sebesar Rp101.280.156,00 yang jauh lebih besar daripada untuk infrastruktur PATD sebesar (-)Rp30.977.539,00.

Tabel 1 menunjukkan jumlah biaya pada masing-masing tahapan analisis biaya hidup aset dan Gambar 3 menunjukkan NPV untuk PATS dan PATD selama 20 tahun umur layan. Nilai positif NPV dari PATS menunjukkan bahwa PATS menguntungkan secara ekonomi untuk 
dibangun. Sebaliknya, nilai negatif pada NPV PATD menunjukkan bahwa PATD tidak menguntungkan secara ekonomi.

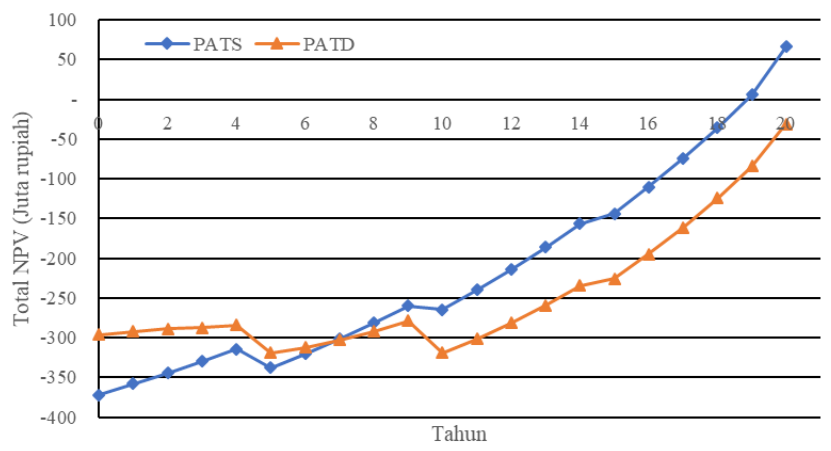

\section{Gambar 3. Biaya penggantian komponen PATS dan PATD}

Perbedaan yang signifikan pada hasil $N P V$ tersebut disebabkan antara lain oleh:

a. Infrastruktur PATS membutuhkan kegiatan perawatan dan perbaikan yang minimal sehingga mengeluarkan biaya yang lebih rendah.

b. Infrastruktur PATS tidak terpengaruh oleh fluktuasi harga bahan bakar minyak berupa diesel sehingga pemasukan untuk PATS dapat dijaga konstan.

c. Komponen panel surya memiliki kemungkinan untuk digunakan kembali (reuse) sehingga meningkatkan nilai penghapusan pada infrastruktur PATS.

Uraian di atas menunjukkan bahwa penggunaan energi terbarukan untuk pengangkatan air baku akan lebih menguntungkan secara ekonomi daripada penggunaan energi konvensional berupa diesel. Hal ini terutama terjadi pada daerah karst tanpa akses terhadap listrik seperti yang terjadi pada beberapa daerah di kawasan karst Gunungsewu.

Tabel 1. Jumlah biaya pada masing-masing tahapan biaya hidup aset

\begin{tabular}{ccr}
\hline \multirow{2}{*}{ Tahapan } & \multicolumn{2}{c}{ Nilai Kini [Rp] } \\
\cline { 2 - 3 } & PATS & \multicolumn{1}{c}{ PATD } \\
\hline Biaya awal & 337.413 .472 & 294.512 .220 \\
\hline Biaya perawatan dan perbaikan & 508.166 .327 & 370.461 .021 \\
\hline Biaya penggantian & -86.290 .071 & -114.273 .192 \\
\hline Biaya penghapusan & 16.817 .372 & 9.373 .812 \\
\hline Total $N P V$ & 101.280 .156 & -30.977 .539 \\
\hline
\end{tabular}

\section{KESIMPULAN}

Analisis biaya hidup aset dilakukan untuk mengetahui aspek ekonomi dari adanya infrastruktur pengangkatan air baku PATS dan PATD di Banyumeneng. Hasil analisis menunjukkan bahwa untuk sistem PATS, biaya awal dari sistem adalah sebesar Rp334.413.472,00; nilai kini untuk biaya perawatan dan perbaikan berupa biaya bersih pemasukan adalah sebesar Rp508.166.327,00; total nilai kini biaya penggantian untuk 20 tahun umur layan adalah sebesar (-)Rp86.290.071,00 dan biaya pendapatan dari penghapusan adalah sebesar $\mathrm{Rp} 16.817 .372,00$. Nilai NPV dari infrastruktur PATS Banyumeneng adalah sebesar Rp101.280.156,00. Nilai positif pada total Net Present Value menunjukkan bahwa infrastruktur PATS Banyumeneng menguntungkan secara ekonomi untuk dibangun. 
Pada sistem PATD, hasil analisis menunjukkan bahwa biaya awal dari sistem adalah sebesar Rp294.512.220,00; nilai kini untuk biaya perawatan dan perbaikan adalah sebesar Rp370.461.021,00; total nilai kini biaya penggantian untuk 20 tahun umur layan adalah sebesar (-)Rp114.273.192,00 dan biaya pendapatan dari penghapusan adalah sebesar Rp.9.373.812,00. Nilai NPV dari infrastruktur PATD Banyumeneng adalah sebesar (-)Rp30.997.539,00. Nilai negatif pada total nilai kini menunjukkan bahwa infrastruktur PATD Banyumeneng tidak menguntungkan secara ekonomi untuk dibangun.

Dari analisis biaya hidup infrastruktur pengangkatan air menggunakan PATS dan PATD, diketahui bahwa penggunaan energi terbarukan akan lebih menguntungkan secara ekonomi untuk dibangun daripada menggunakan energi diesel. Selain itu, nilai positif pada total $N P V$ juga menunjukkan bahwa pengelola akan memiliki kondisi finansial yang kuat untuk mengoperasikan PATS selama umur layan. Pada akhirnya, kekuatan finansial pengelola tersebut diharapkan mampu menjamin keberlanjutan sistem dari infrastruktur PATS terbangun.

\section{DAFTAR RUJUKAN}

Adji, T. N., Haryono, E., \& Woro, S. (1999). Kawasan Karst dan Prospek Pengembanganya di Indonesia. Seminar PIT IGI UI.

Agrawal, B., \& Tiwari, G. (2010). Life cycle cost assessment of building integrated photovoltaic thermal (BIPVT) systems. Energy and Buildings 42 (2010), 1472-1481.

Bank Indonesia. (2018, Juni 11). https://www.bi.go.id/en/moneter/inflasi/data/Default.aspx, https://www.bi.go.id/id/moneter/bi-rate/data/Default.aspx.

Ford, D., \& Williams, P. (2007). Karst Hydrogeology and Geomorphology. West Sussex: John Wiley \& Sons Ltd.

GIZ. (2006). Frequently Asked Questions on Solar Powered Irrigation Pumps. New Delhi: GIZ.

Setiawan, A. A., Purwanto, H. D., Pamuji, D. S., \& Huda, N. (2014a). Development of a Solar Water Pumping System in Karsts Rural Area Tepus, Gunungkidul through Student Community Services. Energy Procedia 47(2014), 7-14.

Setiawan, A. A., Ramadhan, S. A., Wahyuni, N. S., Hidayah, A. N., Arifin, R., \& Suyatna, H. (2014b). Economic Analysis Comparison Between Solar Photovoltaic and Diesel Generator for Water Pumping System in an Indonesia Rural Karsts Area. $3^{\text {rd }}$ EBTKE CONEX.

Setiawan, C. (2014). Kajian Sistem Pengangkatan Air Tenaga Surya di Gua Plawan, Desa Giricahyo, Kecamatan Panggang, Kabupaten Gunungkidul. Yogyakarta: Jurusan Teknik Fisika Universitas Gadjah Mada.

Wahyuni, N. S., Wulandari, S., Wulandari, E., \& Pamuji, D. S. (2015). Integrated Communities for the Sustainability of Renewable Energy Application: Solar Water Pumping System in Banyumeneng Village, Indonesia. Energy Procedia 79 (2015), 1027-1032.

Widiyanti, W., \& Dittmann, A. (2014). Climate Change and Water Scarcity Adaptation Strategies in the Area of Pacitan, Java Indonesia. Procedia Environmental Sciences 20 (2014), 693-702. 